\title{
EFFECTS OF CONTACT HISTORY AND FAMILY INCOME ON THE RISK OF PULMONARY TUBERCULOSIS IN PADANGSIDIMPUAN, NORTH SUMATERA
}

\author{
Suryani, Fazidah Aguslina, Wirsal Hasan \\ Masters Program in Public Health, Universitas Sumatera Utara
}

\begin{abstract}
Background: Tuberculosis (TB) remains one of the world's deadliest communicable diseases. In 2016, 10.4 million people fell ill with TB, and 1.7 million died from the disease (including 0.4 million among people with HIV). Over 95\% of TB deaths occur in low and middle-income countries. Seven countries account for $64 \%$ of the total, with India leading the count, followed by Indonesia, China, Philippines, Pakistan, Nigeria, and South Africa. Given that most deaths from TB are preventable, the death toll from the disease is still unacceptably high and efforts to combat it must be accelerated. This study aimed to determine the effects of contact history and family income on the risk of pulmonary TB in Padangsidimpuan, North Sumatera.
\end{abstract}

Subejcts and Method: This was a case control study conducted at several Puskesmas (Community Health Center) in Padangsidimpuan, North Sumatera. A total of 90 patients consisting of 45 TB cases and 45 controls were selected for this study. The dependent variable was pulmonary TB. The independent variables were contact history and family income. Pulmonary TB cases were determined by sputum acid fast tuberculosis (AFT) bacilli test. The other data were collected by questionnaire. The data were analyzed by a multiple logistic regression.

Results: The risk of pulmonary $\mathrm{TB}$ increased with history of $\mathrm{TB}$ contact $(\mathrm{OR}=$ $4,01 ; 95 \% \mathrm{CI}=1.67$ to $9.66 ; \mathrm{p}=0.002)$ and low family income $(\mathrm{OR}=2.53 ; 95 \% \mathrm{CI}=$ 1.07 to $5.9 ; \mathrm{p}=0.033$ ).

Conclusion: The risk of pulmonary TB increases with history of TB contact and low family income.

Keywords: pulmonary tuberculosis, tuberculosis contact, family income.

\section{Correspondence:}

Suryani. Masters Program in Public Health, Universitas Sumatera Utara, Jl. Prof. T. Maas, Medan, North Sumatera. Email: suryanigoharahap@gmail.com.

Mobile: 081362176052

The 4th International Conference on Public Health

Best Western Premier Hotel, Solo, Indonesia, August 29-30, 2018 | 79

https://doi.org/10.26911/theicph.2018.01.40 